\title{
STUDI PERALIHAN DAYA LISTRIK DARI PLN KE GENERATOR SET (GENSET) KETIKA TERJADI PEMADAMAN DARI PLN DENGAN UNINTERRUPTIBLE POWER SUPPLY (UPS) PADA HOTEL GRAND ELITE PEKANBARU
}

\author{
Nomon Muranto ${ }^{1}$, Atmam $^{2}$, Zulfahri $^{3}$ \\ Program Studi Teknik Elektro, Fakultas Teknik, Universitas Lancang Kuning Pekanbaru. \\ Jl. Yos Sudarso Km. 8 Rumbai, Pekanbaru, Telp. (0761) 52324 \\ Email : momonmurantoe26@gmail.com, atmam@unilak.ac.id, zulfahri@unilak.ac.id
}

\begin{abstract}
ABSTRAK
Hotel Grand Elite Pekanbaru mendapat suplai daya listrik dari PLN sebesar 1250 kVA dan mempunyai tiga buah unit Generator-set (Genset) kapasitas $500 \mathrm{kVA}$ sebagai back-up suplai daya listrik apabila terjadinya pemadaman listrik dari PLN. Namun demikian penggunaan genset tersebut tidak dapat melayani beban secara cepat dimana hal ini disebabkan adanya kerusakan pada rangkaian Automatic Transfer Switch (ATS). Untuk itu diperlukan rancangan sistem suplai daya tak terputus yang dapat menyuplai beban, khususnya beban emergency dengan menggunakan Uninterruptible Power Supply (UPS). Dari hasil penelitian diperoleh total beban emergency Hotel Grand Elite Pekanbaru sebesar 125,779 kVA terdiri dari beban lift 32,670 kVA dan beban Elite Fitnes Center 67,952 kVA sehingga diperlukan kapasitas UPS sebesar 150 kVA. Penambahan suplai daya UPS sangat cocok karena disamping sebagai solusi akibat kurangnya daya listrik ketika terjadi pemadaman dari PLN dan juga dapat memback-up beban emergency pada Hotel Grand Elite Pekanbaru.
\end{abstract}

Kata kunci : Generator-set, Uninterruptible Power Supply

\begin{abstract}
Grand Elite Pekanbaru Hotel gets electricity supply from PLN of $1250 \mathrm{kVA}$ and has three units of Generator-set (Genset) capacity of $500 \mathrm{kVA}$ as a back-up of electricity supply if there is a power outage from PLN. However, the use of these gensets cannot serve loads quickly where this is caused by damage to the Automatic Transfer Switch (ATS) circuit. For this reason, it is necessary to design an uninterruptible power supply system that can supply loads, especially emergency loads using Uninterruptible Power Supply (UPS). From the results of the study, the total emergency load of the Grand Elite Pekanbaru Hotel was 125,779 kVA consisting of lift loads of 32,670 kVA and Elite Fitness Center load of 67,952 kVA, so that UPS capacity was needed at $150 \mathrm{kVA}$. The addition of UPS power supply is very suitable because besides being a solution due to lack of electricity when there is a blackout from the PLN and also can back up emergency loads at the Grand Elite Hotel Pekanbaru.
\end{abstract}

Keywords: Electrical Powet Supply, Generator Set, Uninterruptible Power Supply

\section{PENDAHULUAN}

Perkembangan teknologi pada bisnis perhotelan di Pekanbaru semakin berkembang sehingga memperketat persaingan di bisnis perhotelan, untuk mengurangi dampak persaingan tersebut beberapa hotel yang berada di Pekanbaru bertindak praktis dengan menambah fasilitas-fasilitas pendukung yang sebagian besar memerlukan tenaga listrik sebagai alat operasionalnya, Hal ini dilakukan demi tingginya
Occupancy (tingkat-hunian kamar) di hotel masingmasing.

Adapun fasilitas pendukung tersebut berupa lift, fasilitas Elite Fitnes Center yang didalamnya terdapat (Hot Pool, Warm Pool, Cool Pool), serta peralatan listrik lainya, seperti penerangan dan pengolahan data (komputer). Sebagian peralatan listrik tersebut termasuk dalam beban emergency yang sangat membutuhkan suplai daya, meski terjadi pemadaman listrik dari PLN. 
Penggunaan genset pada hotel sangat penting untuk melayani beban emergency pada saat ada pemadaman dari PLN, akan tetapi genset tersebut tidak dapat melayani beban secara cepat karena memerlukan waktu untuk dapat mensuplai daya, hal ini ditambah lagi dengan kerusakan pada rangkaian Automatic Transfer Switch (ATS), sehingga memerlukan jaminan bahwa dalam kondisi normal maupun emergency, suplai daya listrik harus disuplai terus-menerus melalui Uninterruptible Power Supply (UPS).

Ada beberapa yang harus dipertimbangkan dalam pemasangan UPS adalah sebagai berikut:

1. Pengelompokan beban-beban yang harus dilayani oleh UPS tersebut harus dipisahkan dari beban keseluruhan, karena apabila terjadi gangguan pada PT PLN tidak akan berpengaruh pada sistem kelistrikan hotel yang mempengaruhi pada bebanbeban emergency.

2. Jenis beban yang disuplai oleh UPS

3. Berapa besar kemampuan dari sistem UPS yang akan dipasang harus sesuai dengan beban emergency yang telah direncanakan, sehingga UPS tersebut tidak terlalu kecil.

Dengan demikian dapat ditentukan kapasitas UPS yang terpasang pada bangunan Hotel Grand Elite Pekanbaru, sehingga tidak terjadi kelebihan beban, sesuai dengan kemampuan UPS tersebut.

\section{METODE PENELITIAN}

Untuk menyelesaikan masalah sistem suplai daya pada Hotel Grand Elite Pekanbaru maka dilakukan langkah-langkah sebagai berikut :

a. Mengumpulkan data teknis dilapangan yaitu data beban dan data suplai daya dari PLN ke Hotel Grand Elite Pekanbaru.

b. Menganalisa kapasitas suplai daya pada PLN, genset dan UPS.

c. Mengelompokkan beban umum dan beban emergency.

d. Melakukan perencanaan pemasangan UPS terhadap beban emergency.

e. Pemilihan UPS yang tepat untuk beban emergency.

f. Analisis anggaran investasi perencanaan UPS.

g. Analisis pemakaian UPS terhadap beban emergency.

\section{Daya dan Faktor daya}

Daya adalah suatu ukuran terhadap penggunaan energi dalam suatu waktu tertentu, dengan menggunakan persamaan : [1].

$$
P=\frac{W}{t}
$$

Keterangan :

$$
\begin{array}{ll}
P & =\text { Daya (Watt) } \\
W & =\text { Energi (kWh) } \\
t & =\text { Waktu (detik) }
\end{array}
$$

Daya Kompleks atau lebih sering dikenal sebagai daya semu adalah penjumlahan secara vektor antara daya aktif dan daya reaktif, menggunakan persamaan : [2].

$$
S=P+j Q
$$

Keterangan :

$$
\begin{aligned}
& S=\text { Daya semu (VA) } \\
& P \quad=\text { Daya aktif (Watt) } \\
& Q \quad=\text { Daya reaktif (VAR) }
\end{aligned}
$$

Daya kompleks dinyatakan dengan satuan VA (Volt Amper) adalah hasil kali antara besarnya tegangan dan arus listrik yang mengalir pada beban. Dapat dirumuskan menggunakan persamaan : [2]

$$
S=\sqrt{3} \times V \times I
$$

Keterangan :

$S \quad=$ Daya semu (VA)

$V \quad=$ Tegangan (Volt)

$I \quad=$ Arus Listrik (Amper)

Hubungan ketiga daya listrik yaitu daya aktif $(P)$, daya reaktif $(Q)$ serta daya semu $(S)$, dinyatakan dengan sebuah segitiga, yang disebut dengan segitiga daya. Seperti pada Gambar 1 [2].

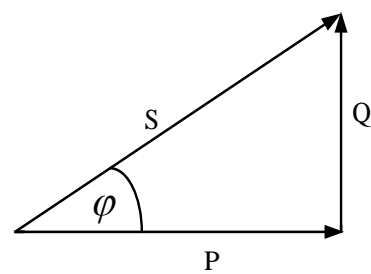

Gambar 1. Segitiga Daya

Dari gambar segitiga daya seperti pada gambar 1 hubungan antara ketiga daya listrik, dapat dinyatakan sesuai persamaan berikut [2].

$$
\begin{aligned}
& S=\sqrt{3} \times V \times I \\
& P=\sqrt{3} \times V \times I \times \operatorname{Cos} \varphi=S \times \operatorname{Cos} \varphi \\
& S=\frac{P}{\operatorname{Cos} \varphi} \\
& Q=\sqrt{3 \times V} \times I \times \operatorname{Sin} \varphi \\
& \operatorname{Cos} \varphi=p f=\frac{\mathrm{P}}{\mathrm{S}}
\end{aligned}
$$


$\varphi$ adalah sudut daya aktif dan daya semu sehingga $\operatorname{Cos} \varphi$ didefinisikan adalah faktor daya (Power factor). Untuk beban yang bersifat induktif, Pf lagging dimana arusnya tertinggal dari tegangannya, dan untuk beban yang bersifat kapasitif, Pf leading di mana arusnya mendahului tegangannya [2].

\section{HASIL DAN PEMBAHASAN}

Adapun suplai daya listrik pada Hotel Grand Elite Pekanbaru diperoleh dari:

\section{Sistem tenaga listrik dari gardu distribusi PLN}

Pada proses operasionalnya Hotel Grand Elite Pekanbaru memerlukan suplai daya listrik langsung dari PLN. Suplai daya listrik tersambung sebesar 850 kVA. Pada proses penyaluran daya listrik dari PLN di distribusikan melalui panel distribusi tegangan menengah $20 \mathrm{kV}$.

Kemudian dari panel distribusi tegangan menengah diturunkan menjadi 380 Volt dengan menggunakan satu buah transformator yang memiliki kapasitas $1250 \mathrm{kVA}$. Setelah itu, disalurkan kembali melalui Panel Distribusi Tegangan Rendah (PDTR) yang diparalelkan dengan 3 buah Panel Control Genset (PKG) dengan kapasitas 500 kVA.

Dari Panel Control Genset disalurkan kembali ke panel-panel distribusi yang langsung disalurkan kebeban melalui Miniatur Circuit Breaker (MCB) pada panel tersebut. Adapun data spefikasi dari trafo daya sebagai suplai dari PLN sebagai berikut :

$\begin{array}{ll}\text { Merek } & : \text { Siemen } \\ \text { Daya } & : 1250 \mathrm{kVA} \\ \text { Standar } & : \text { IEC 76 / SPLN N50 } \\ \text { Pendingin } & : \text { ONAN } \\ \text { Tegangan } & : 20 \mathrm{kV} \\ \text { Frekuensi } & : 50 \mathrm{~Hz} \\ \text { Phasa } & : 3 \text { phasa } \\ \text { Kenaikan suhu oli } & : 60^{\circ} \text { Celcius } \\ \text { Kenaikan suhu belitan } & : 65^{\circ} \text { Celcius } \\ \text { Impedensi } & : 5,5 \%\end{array}$

\section{Sistem tenaga listrik dari pembangkit sendiri berupa genset.}

Untuk suplai daya cadangan Hotel Grand Elite Pekanbaru mempunyai tiga unit genset, yang dilengkapi dengan peralatan Automatic Start yakni, Automatic Transfer switch (ATS) yang disetting pada waktu delay 5-10 detik, ATS adalah saklar otomatis yang bekerja disaat ketika terjadi pemadaman listrik dari PLN. Dalam pengoperasiannya genset tersebut dipasang secara sinkron dengan tegangan kerja 380 $\mathrm{V}$ line to line pada frekuensi $50 \mathrm{~Hz}$.

Pemanfaatan genset ini diperlukan hanya dalam keadaan darurat yaitu pada saat pemadaman dari PLN dan juga apabila adanya kekurangan daya disaat tingkat hunian kamar (occupancy) tinggi. Spesifikasi Genset Hotel Grand Elite Hotel Pekanbaru seperti pada tabel 1. Diagram satu garis sistem suplai daya pada Hotel Grand Elite Pekanbaru seperti pada Gambar 2.

Tabel 1. Spesifikasi Genset Pada Hotel Grand Elite Pekanbaru

\begin{tabular}{ccccccccc}
\hline Merek & $\begin{array}{c}\text { Kapasitas } \\
(\mathbf{k V A})\end{array}$ & Cos $\varphi$ & $\begin{array}{c}\text { Rated } \\
\text { Voltage }\end{array}$ & Phase & $\begin{array}{c}\text { Frekuensi } \\
(\mathbf{H z})\end{array}$ & $\begin{array}{c}\text { Rated } \\
\text { Current }\end{array}$ & $\begin{array}{c}\text { Rated } \\
\text { rpm }\end{array}$ \\
\hline Genset 1 & Daewoo & 500 & 0,8 & 380 & 3 & 50 & 793,9 & 1500 \\
Genset 2 & Merci & 500 & 0,8 & 380 & 3 & 50 & 793,9 & 1500 \\
Genset 3 & Merci & 500 & 0,8 & 380 & 3 & 50 & 793,9 & 1500 \\
\hline
\end{tabular}




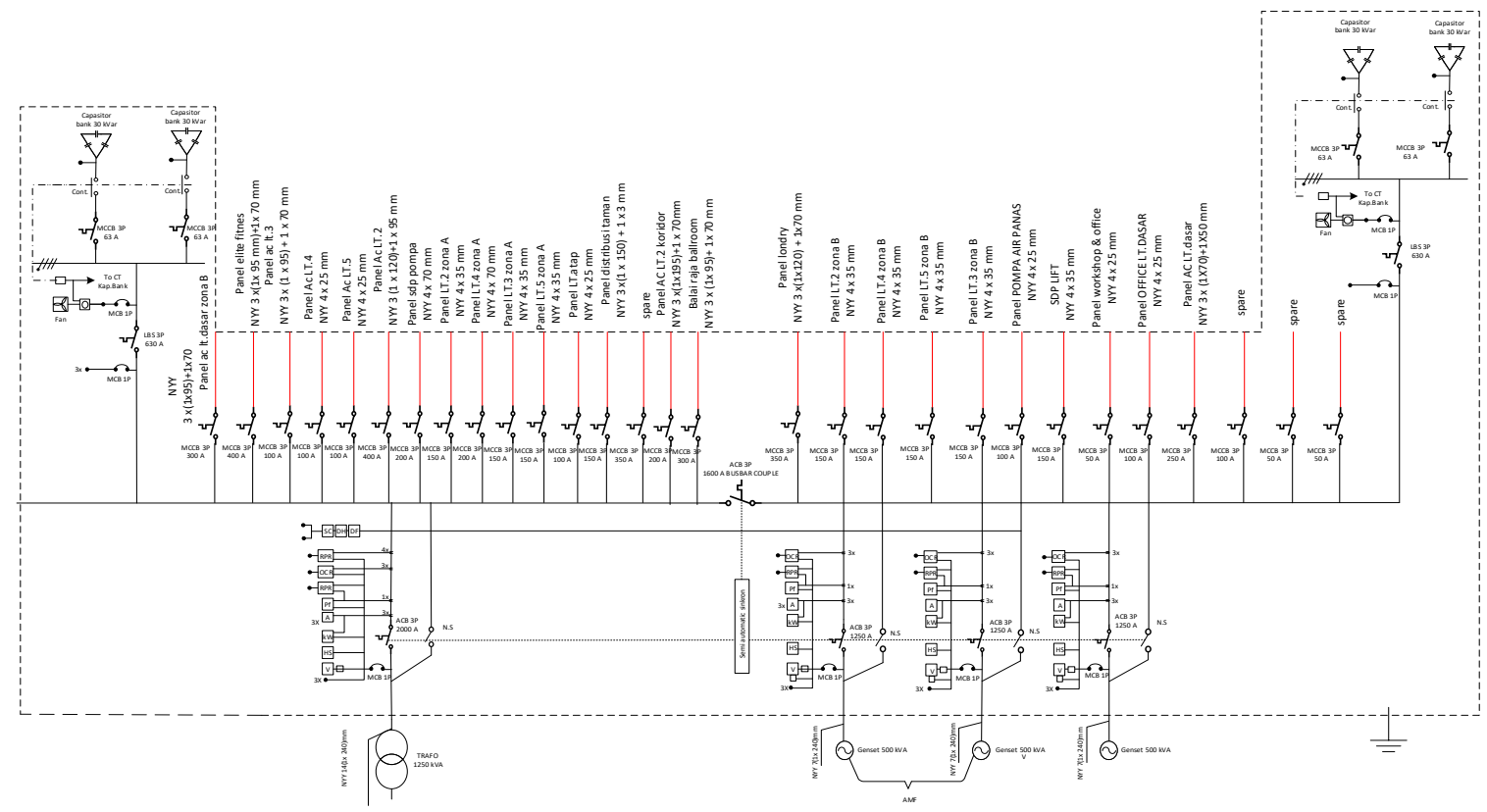

Gambar 2. Diagram Sistem Suplai Daya Pada Hotel Grand Elite Pekanbaru (Sumber : Grand Elite Hotel Pekanbaru)

\section{Panel ATS dan AMF}

Di dalam panel ATS-AMF terdapat beberapa rangkaian elektrik yang memiliki fungsi sebagai saklar yang beroperasi otomatis bila terjadi pemutusan arus listrik yang tidak terencana atau mendadak, maka secara otomatis ATS-AMF akan bekerja sendiri memindahkan switch dan mengambil sumber listrik dari mesin genset atau diesel. Dimana kedua peralatan tersebut bekerja ketika terjadi pemadaman daya listrik dari PLN digantikan dengan genset dan sebaliknya.

\section{Uninterruptible Power Supply (UPS)}

Pada hotel Grand Elite Pekanbaru hanya mempunyai 2 jenis UPS yang berfungsi sebagai back-up langsung energi listrik bila terjadi gangguan pemadaman dari PLN, UPS tersebut hanya berfungsi sebagai perangkat tambahan dan back-up pada komputer dan CCTV apabila terjadi gangguan dari PLN. Spesifikasi UPS pada Hotel Grand Elite Pekanbaru pada Tabel 2.

Tabel 2 Spesifikasi dari UPS pada hotel Grand Elite Pekanbaru

\begin{tabular}{cccccc}
\hline Tipe & $\begin{array}{c}\text { Kapas } \\
\text { itas } \\
\text { (VA) }\end{array}$ & $\begin{array}{c}\text { Output } \\
(\text { Volt })\end{array}$ & $\begin{array}{c}\text { Input } \\
(\text { Volt })\end{array}$ & $\begin{array}{c}\text { Frek. } \\
(\mathbf{H z})\end{array}$ & Dipasang \\
\hline \multirow{2}{*}{ CS1238 } & 1200 & 220 & $\begin{array}{c}160- \\
220\end{array}$ & 50 & $\begin{array}{c}\text { Sebagai Back-up } \\
\text { semua sistem dan } \\
\text { komputer }\end{array}$ \\
SIN5100C & 2500 & 220 & $\begin{array}{c}160- \\
220\end{array}$ & 50 & $\begin{array}{c}\text { Sebagai Back-up } \\
\text { CCTV }\end{array}$ \\
\hline
\end{tabular}

\section{Pembebanan}

Beban daya listrik pada gedung Hotel Grand Elite Pekanbaru dapat dikategorikan menjadi dua kategori yakni :

\section{a. Beban Umum}

Beban umum adalah beban yang bersifat umum dimana beban tersebut masih diizinkan sampai adanya suplai daya dari pembangkit sendiri apabila terjadi pemutusan atau gangguan pada suplai daya PLN. Dari hasil pendataan beban yang terpasang di Hotel Grand Elite Pekanbaru adalah disuplai dengan satu sumber, dimana satu unit transformator dengan rating tegangan 380 Volt dan kapasitas Trafo sebesar $1.250 \mathrm{kVA}$, dan beban terpasang pada hotel sebesar 1,926,076 Watt sementara beban yang terpasang pada genset ketika terjadi gangguan dari PLN sebesar 1,339,006 Watt.

\section{b. Beban Emergency}

Beban emergency adalah beban yang dikategorikan apabila terjadi pemutusan suplai daya listrik tidak boleh putus karena dapat merugikan operasional jasa pelayanan pada hotel dan kenyamanan pada tamu, dan untuk beban emergency yang sudah terback-up UPS pada Hotel Grand Elite Pekanbaru yaitu beban pengolah data (personal Computer) dan CCTV, sementara untuk beban emergency yang belum terback-up oleh UPS seperti pada Tabel 3.

Adapun permasalahan yang timbul pada sistem peralihan daya listrik dari genset ke PLN adalah sebagai berikut: 
1. Kehandalan tiga buah generator-set (genset) tersebut sudah kurang mendukung, disebabkan faktor usia dan instalasinya sejak tahun 2006.
2. ATS-AMF tidak berjalan maksimal karena adanya kerusakan disistem ATS-AMF itu sendiri, hal ini di sebabkan oleh faktor usia.

Tabel 3. Pengelompokan Beban Emergency Yang Belum Terpasang UPS.

\begin{tabular}{clccc}
\hline NO & Jenis Beban & $\begin{array}{c}\text { Jumlah } \\
\text { Unit }\end{array}$ & Besarnya Daya (Watt) & $\begin{array}{c}\text { Daya } \\
\text { Terpasang } \\
\text { (Watt) }\end{array}$ \\
\hline 1 & Beban Lift & 3 & 8712 & 26.136 \\
2 & Peralatan Elite fitness & & 54.363 & 54.363 \\
\hline
\end{tabular}

1. Besaran arus yang terpasang pada bangunan Hotel Grand Elite Pekanbaru

Berdasarkan data diketahui jumlah daya yang terpasang sebesar 1.926.076 Watt sehingga diperoleh arus sebagai berikut [3]:

$$
I_{\text {Load }}=\frac{P}{\sqrt{3} \times V \times \operatorname{Cos} \varphi}=\frac{1.926 .076 \mathrm{Watt}}{\sqrt{3} \times 380 \times 0,8}=3.658 \mathrm{Amper}
$$

\section{Kuat arus yang dikeluarkan transfomator}

Besarnya daya dari transfomator utama pada Hotel Grand Elite Pekanbaru sebesar 1250 kVA dengan tegangan $20 \mathrm{kV}$. Untuk menghitung arus nominal sisi primer, sisi sekunder dan arus arus tiga pasa pada transfomator adalah sebagai berikut:

a. Arus nominal sisi primer [4]

$$
\begin{aligned}
& I=\frac{S}{\sqrt{3} \times \mathrm{V}} \\
& I_{P}=\frac{S}{\sqrt{3} \times V}=\frac{1.250 . \mathrm{kVA}}{\sqrt{3} \times 20 \mathrm{kV}}=36,08 \text { Amper }
\end{aligned}
$$

b. Arus nominal sisi sekunder [4]

$$
I_{S}=\frac{S}{\sqrt{3} \times V}=\frac{1.250 .000 \mathrm{VA}}{\sqrt{3} \times 380 \mathrm{~V}}=1.899 \text { Amper }
$$

c. Berdasarkan standar IEC (International Electrical Commition 60947-2) maka arus nominal pada CB yang mengalir dari sumber trafo adalah :

$$
\begin{aligned}
I_{c b} & =\left(150 \% \times I_{n}\right) \\
& =(150 \% \times 1899 \mathrm{~A}) \\
& =2849 \text { Amper }
\end{aligned}
$$

\section{Kuat Arus Yang Dikeluarkan Generator Set (Genset )}

Besarnya daya generator set (genset) yang tersedia pada Hotel Grand Elite Pekanbaru adalah sebesar $3 \times 500 \mathrm{kVA}$

a. Daya aktif pada genset [4]

$$
\begin{aligned}
P & =S \times \operatorname{Cos} \varphi \\
P & =S \times \operatorname{Cos} \varphi \\
& =1.500 .000 \mathrm{VA} \times 0,8 \\
& =1.200 .000 \text { Watt }
\end{aligned}
$$

b. Arus yang mengalir pada genset [4]

$$
I_{\text {Load }}=\frac{\mathrm{S}}{\sqrt{3} \times V}=\frac{1.500 .000 \mathrm{VA}}{\sqrt{3} \times 380}=2279 \text { Amper }
$$

Sehingga setiap unit genset mengeluarkan arus sebesar [4]

$I_{\text {Unit }}=\frac{I_{\text {Load }}}{\text { Unit }}=\frac{2279 \mathrm{~A}}{3}=759$ Amper

c. Kapasitas arus beban hotel Grand Elite Pekanbaru ketika terjadi pemadaman dari PLN

$$
I=\frac{P}{\sqrt{3} \times V \times \operatorname{Cos} \varphi}=\frac{1.339 .006}{\sqrt{3} \times 380 \times 0,8}=2.543 \text { Amper }
$$

maka setiap unit genset mengeluarkan arus apabila terjadi pemadaman dari PLN,

$$
I_{\text {Unit }}=\frac{I_{\text {Load }}}{\text { Unit }}=\frac{2543 \mathrm{~A}}{3}=847,6 \text { Ampere }
$$

d. Berdasarkan standar dari IEC (International Electrical Commition 609472) sehingga arus nominal pada CB yang mengalir dari sumber genset adalah :

$$
\begin{gathered}
I C B=(150 \% \times \text { In }) \\
=(150 \% \times 2543 A) \\
=3814 \text { Amper }
\end{gathered}
$$

Sesuai dari hasil perhitungan diatas diketahui arus yang mengalir pada 3 unit genset adalah sebesar 2.279 Amper di setiap unitnya menghasilkan arus sebesar 759 Amper sedangkan beban terpasang sebesar $1.339 \mathrm{~kW}$ sementara itu arus beban yang mampu di back-up sebesar $1200 \mathrm{~kW}$ sehingga kekurangan beban saat pemadaman PLN $139 \mathrm{~kW}$ dan arus nominalnya sebesar 2.543 Amper, sehingga diketahui beban yang terpasang jauh melebihi kapasitas genset, maka harus ditambah power supply untuk mengurangi daya tersebut.

\section{Sistem back-up UPS}

Pada Hotel Grand Elite Pekanbaru mempunyai 2 jenis UPS yang berfungsi sebagai suplai daya tak putus pada beban emergency, adapun dua jenis UPS tersebut adalah sebagai berikut: 
a. UPS model CS 1238

UPS CS 1238 jenis ini digunakan sebagai backup sistem pada komputer dan diletakan tidak jauh dari komputer, dengan menggunakan data spesifikasi maka diperoleh arus yang di suplai oleh UPS adalah :

$$
I=\frac{S}{\sqrt{3} \times V}=\frac{1.200 \mathrm{VA}}{\sqrt{3} \times 220 \text { Volt }}=4,6 \text { Amper }
$$

Selanjutnya menghitung daya aktif pada UPS tersebut sebagai berikut [5] :

$$
P=S \times \operatorname{Cos} \varphi=1.200 \times 0,85=1.020 \mathrm{Watt}
$$

Sehingga arus yang mengalir pada UPS tersebut sebesar 4,6 Amper dan daya aktif yang bisa di backup sebesar 1.020 Watt dan beban dari komputer sebesar 450 Watt. Hal ini sesuai dengan kemampuan back-up peralalatan pengolahan data dan personal komputer.

\section{b. UPS model SIN $5100 \mathrm{C}$}

UPS SIN $5100 \mathrm{C}$ jenis ini biasanya digunakan sebagai back-up dengan kapasitas rendah. dengan mengunakan data spesifikasi maka diperoleh beban yang disuplai oleh UPS ini. Arus yang mengalir pada UPS SIN $5100 \mathrm{C}$ adalah [5] :

$$
I=\frac{S}{\sqrt{3} \times V}=\frac{2.500 \mathrm{VA}}{\sqrt{3} \times 220 \mathrm{~V}}=6,4 \text { Amper }
$$

Selanjutnya dapat dihitung daya aktif pada UPS sebagai berikut [5] :

$$
P=S \times \operatorname{Cos} \varphi=2.500 \times 0,85=2.000 \text { Watt }
$$

Jumlah beban CCTV seperti pada Tabel 4.1

Tabel 4.1 Jumlah beban CCTV

\begin{tabular}{cccc}
\hline Beban & $\begin{array}{c}\text { Daya } \\
\text { (Watt) }\end{array}$ & Jumlah & $\begin{array}{c}\text { Total } \\
\text { (Watt) }\end{array}$ \\
\hline DVR/ Perekam & 75 & 3 & 225 \\
Kamera & 9 & 42 & 378 \\
Monitor & 80 & 10 & 800 \\
\hline \multicolumn{5}{c}{ Total } \\
\hline
\end{tabular}

Sehingga dapat disimpulkan arus yang mengalir pada UPS tersebut sebesar 6,4 Amper dan daya aktif yang bisa di back-up sebesar 2.000 Watt. Hal ini sesuai dengan kemampuan memback-up sistem CCTV dan peralatannya.

\section{Kapasitas UPS}

Untuk mengetahui besarnya kapasitas pemasangan UPS pada bangunan Hotel Grand Elite Pekanbaru bisa dilakukan beberapa tahap yakni: a. Perhitungan beban emergency.

Untuk mengetahui beban emergency yang dibutuhkan pada Hotel Grand Elite Pekanbaru. Terlebih dahulu kita kelompokan beban, adapun data beban emergency sebesar 80.499 Watt yang harus dipenuhi oleh UPS sehingga penentuan jenis UPS sebaiknya kita cari kapasitas beban sebagai berikut :

1. Beban Lift

$$
\begin{aligned}
S & =\frac{P}{\operatorname{Cos} \varphi}=\frac{26.136 \mathrm{~W}}{0,8}=32.670 \mathrm{VA} \\
S_{U P S} & =125 \% \times 26136=40.837 \mathrm{VA}
\end{aligned}
$$

2. Beban Elite Fitnes Center

$$
\begin{aligned}
S & =\frac{P}{\operatorname{Cos} \varphi}=\frac{54.363 \mathrm{~W}}{0,8}=67.953 \mathrm{VA} \\
S_{U P S} & =125 \% \times 67.953=84.942 \mathrm{VA}
\end{aligned}
$$

3. Sehingga kapasitas UPS yang akan dipasang adalah :

$$
S_{U P S}=40.837 \mathrm{VA}+84.942 \mathrm{VA}=125.779 \mathrm{VA}
$$

Dengan beban emergency sebesar 125.779 VA maka dibutuhkan UPS dengan kapasitas 150.000 VA atau $150 \mathrm{kVA}$

6. Spesifikasi Rancangan Instalasi

a. Rating MCB (A)

Untuk menentukan rating MCB sebagai berikut:

1. Beban Lift

$$
I_{n}=\frac{P}{V \times \operatorname{Cos} \varphi}=\frac{32.760 \mathrm{~W}}{380 \times 0,8}=108 \text { Amper }
$$

Dengan menggunakan standar IEC (International Electrical Commition 60947) sehingga arus CB adalah :

$$
\begin{aligned}
I_{C b} & =\left(150 \% \times I_{n}\right) \\
& =150 \% \times 108 \\
& =162 \text { Amper }
\end{aligned}
$$

2. Beban Elite Fitnes Center sesuai adalah :

$$
I_{n}=\frac{P}{V \times \operatorname{Cos} \varphi}=\frac{67.954 \mathrm{~W}}{380 \times 0,8}=223 \text { Amper }
$$

Dengan menggunakan standar IEC (International Electrical Commition 60947) sehingga arus CB adalah :

$$
\begin{aligned}
I_{C b} & =\left(150 \% \times I_{n}\right) \\
& =150 \% \times 223 \\
& =334 \text { Amper }
\end{aligned}
$$


3. Jika pemasangan CB apabila beban Elite Fitnes Center dan Beban Lift di hubungkan langsung dengan UPS maka :

$$
I_{n}=\frac{P}{V \times \operatorname{Cos} \varphi}=\frac{125778 \mathrm{~W}}{380 \times 0,8}=414 \text { Amper }
$$

Dengan menggunakan standar IEC (International Electrical Commition 60947) sehingga arus CB adalah :

$$
\begin{aligned}
I_{C b} & =\left(150 \% \times I_{n}\right) \\
& =150 \% \times 414 \\
& =621 \text { Amper }
\end{aligned}
$$

\section{b. Kapasitas arus penampang}

Untuk menghitung kapasitas arus penampang sebagai berikut [6]:

1. Kapasitas arus beban lift

$$
I_{n}=\frac{P}{V}=\frac{26.136 \mathrm{~W}}{380 \mathrm{~V}}=69 \text { Amper }
$$

2. Kapasitas arus beban Elite Fitnes Center

$$
I_{n}=\frac{P}{V}=\frac{54.363 \mathrm{~W}}{380 \mathrm{~V}}=143 \text { Amper }
$$

3. Sehingga total kedua beban tersebut :

26.136 Watt $+54.363 \mathrm{Watt}=80.499 \mathrm{Watt}$

Maka arus yang mengalir di kedua beban adalah :

$$
I_{n}=\frac{P}{V}=\frac{80.449}{380 \mathrm{~V}}=212 \text { Amper }
$$

\section{c. Luas penampang ke UPS}

1. Untuk luas penampang beban lift

$$
\begin{aligned}
A & =\frac{(2 \times L) \times(I) \times \operatorname{Cos} \varphi}{\tau \times(5 \%) \times V} \\
& =\frac{(2 \times 75 \mathrm{~m}) \times(69) \times 0,8}{5,62 \times 10^{6} \times(5 \%) \times 380} \\
& =\frac{8280 \times 10^{-6} \mathrm{~m}^{2}}{1067,8} \\
& =7,75 \times 10^{-6} \times 1.000 .000 \\
& =8 \mathrm{~mm}^{2}
\end{aligned}
$$

2. Untuk luas penampang beban Elite Fitnes Center

$$
\begin{aligned}
A & =\frac{(2 \times L) \times(I) \times \operatorname{Cos} \varphi}{\tau \times(5 \%) \times V} \\
& =\frac{(2 \times 50) \times(143) \times 0,8}{5,62 \times 10^{6} \times(5 \%) \times 380} \\
& =\frac{11,44 \times 10^{-6} \mathrm{~m}^{2}}{1067,8} \\
& =11,44 \times 10^{-6} \times 1.000 .000 \\
& =11 \mathrm{~mm}^{2}
\end{aligned}
$$

3. Luas penampang ke dua beban Elite Fitnes Center dan beban Lift

$$
\begin{aligned}
A & =\frac{(2 \times L) \times(I) \times \operatorname{Cos} \varphi}{\tau \times(5 \%) \times V} \\
& =\frac{(2 \times 125) \times(212) \times 0,8}{5,62 \times 10^{6}(5 \%) \times 380} \\
& =\frac{60,800 \times 10^{-6} \mathrm{~m}^{2}}{1067,8} \\
& =42,400 \times 10^{-6} \times 1.000 .000 \\
& =42 \mathrm{~mm}^{2}
\end{aligned}
$$

\section{d. Tahanan Penghantar}

Kabel yang digunakan jenis kabel NYY dengan luas penampang sesuai dengan beban dan fungsi, kapasitas, dan ekonomisnya. Untuk menghitung tahanan setiap penghantar pada beban berikut :

1. Beban lift dengan luas penampang $6 \mathrm{~mm}^{2}$ dan memiliki tahanan $2,97 \mathrm{Ohm} / \mathrm{km}$ pada suhu $20^{\circ} \mathrm{C}$ dan panjang saluran 75 meter (BSN, 2000)

$$
\begin{aligned}
R_{30^{\circ} \mathrm{C}} & =R_{20^{\circ} \mathrm{C}}\left[1+\alpha\left(T 30^{\circ} \mathrm{C}-T 20^{\circ} \mathrm{C}\right)\right] \\
& =2,97[1+0.00393(30-20) \\
& =3,08 \mathrm{Ohm} / \mathrm{km} \\
& =3,08: 1000=0,00308 \mathrm{Ohm} / \mathrm{m}
\end{aligned}
$$

2. Beban Elite Fitnes Center dengan luas penampang $10 \mathrm{~mm}^{2}$ dan memiliki tahanan 1,77 $\mathrm{Ohm} / \mathrm{km}$ pada suhu $20^{\circ} \mathrm{C}$ dan panjang saluran 50 meter (BSN, 2000)

$$
\begin{aligned}
R_{30^{\circ} \mathrm{C}} & =R_{20^{\circ} \mathrm{C}}\left[1+\alpha\left(T 30^{\circ} \mathrm{C}-T 20^{\circ} \mathrm{C}\right)\right] \\
& =1,77[1+0.00393(30-20) \\
& =1,83 \mathrm{Ohm} / \mathrm{km} \\
& =1,83: 1000=0,00183 \mathrm{Ohm} / \mathrm{m}
\end{aligned}
$$

3. Luas penampang beban Elite Fitnes Center dan beban Lift adalah $42 \mathrm{~mm}^{2}$ dan memiliki tahanan $0,397 \mathrm{Ohm} / \mathrm{km}$ pada suhu $20^{\circ} \mathrm{C}$ dan panjang saluran 125 meter (BSN, 2000)

$$
\begin{aligned}
R_{30^{\circ} \mathrm{C}} & =R_{20^{\circ} \mathrm{C}} \times\left[1+\alpha \times\left(T 30^{\circ} \mathrm{C}-T 20^{\circ} \mathrm{C}\right)\right] \\
& =0,397 \times[1+0.00393 \times(30-20) \\
& =0,41 \mathrm{Ohm} / \mathrm{km} \\
& =0,41: 1000=0,0041 \mathrm{Ohm} / \mathrm{m}
\end{aligned}
$$

\section{e. Hambatan kawat}

Tahanan total saluran sepanjang 75 meter, 50 meter dan 125 meter dapat dihitung sebagai berikut :

1. Beban Lift

$$
\begin{aligned}
R_{\text {Lift }} & =0,00308 \times \frac{75 \mathrm{~m}}{8 \mathrm{~mm}^{2}} \\
& =0,028 \mathrm{Ohm}
\end{aligned}
$$

2. Beban Elite Fitnes Center

$$
\begin{aligned}
R_{E F C} & =0,00183 \frac{50 \mathrm{~m}}{11 \mathrm{~mm}^{2}} \\
& =0,00831 \mathrm{Ohm}
\end{aligned}
$$


3. Jika pemasangan dengan 1 unit UPS maka

$$
\begin{aligned}
R_{E F C} & =0,0041 \times \frac{125}{42} \\
& =0,0122 \mathrm{Ohm}
\end{aligned}
$$

Untuk diagram instalasi rencana pemasangan UPS pada Hotel Grand Elite Pekanbaru sebaiknya digunakan tipe On-line UPS karena sesuai dengan fungsinya, tipe UPS model ini langsung memback-up beban ketika terjadi pemadaman dari jaringan utama PLN tanpa adanya jeda waktu disamping itu, tipe UPS ini terpisah antara Inverter, Rectifier dan Baterai sehingga memudahkan dalam pemeliharaan UPS tersebut. Untuk rangkaian UPS $150 \mathrm{kVA}$ seperti Gambar 6.

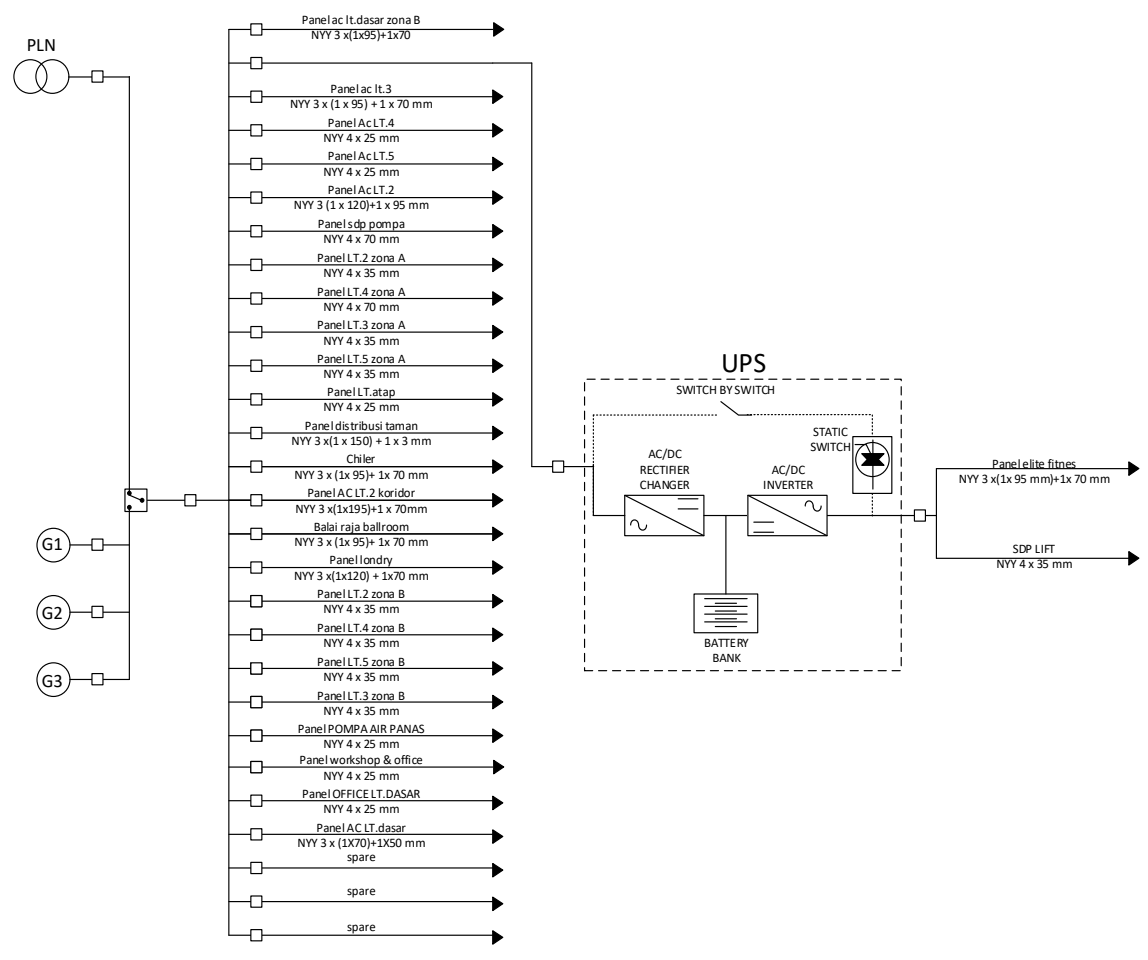

Gambar 6 Diagram Rencana Pemasangan UPS Pada Hotel Grand Elite Pekanbaru

\section{KESIMPULAN}

1. Untuk sistem peralihan daya listrik dari PLN ke genset dengan menggunakan sakelar ATS-AMF sudah sangat efisien dimana sistem ini berfungsi sebagai saklar yang beroperasi otomatis selama 15 detik ketika terjadi pemadaman dari PLN.

2. Untuk menghindari terputusnya suplai daya listrik terhadap beban emergency (beban lift dan beban Elite Fitnes Center) disaat peralihan dari PLN ke genset adalah dengan menggunakan UPS kapasitas $150 \mathrm{kVA}$ terdiri dari beban lift sebesar 32,670 kVA dan beban Elite Fitnes Center sebesar 67,952 kVA.

3. Pemasangan UPS sebesar $150 \mathrm{kVA}$ dapat membantu kekurangan suplai daya listrik pada Hotel Grand Elite Pekanbaru dimana pada saat terjadinya pemadaman dari PLN, hotel masih kekurangan daya sebesar $139 \mathrm{~kW}$ atau sebesar $8,96 \%$.

\section{DAFTAR PUSTAKA}

[1] Suyatmo, F. 2008. Teknik Listrik Arus Searah (ketujuh). Jakarta: Bumi Aksara.

[2] Mufrizon, Eddon. 2016. Inspeksi Pengujian Tenaga Listrik (kedua). Pekanbaru: Dinas Energi Dan Sumber Daya Mineral.

[3] Harvizon. 2005. Analisa Sistem Suplai Daya Pada PT. Indofood Sukses Makmur, Tbk Pekanbaru. Pekanbaru: Tugas Akhir Universitas Lancang Kuning.

[4] Tampubolon, T. 2006. Studi Perencanaan Instalasi Tak Terputus Pada Instrument Loading System di Bandara Sultan Syarif Kasim II Pekanbaru. Universitas Lancang Kuning.

[5] Manfrigos. 2015. Studi Uninteruptible Power Supply (UPS) Tipe Online Untuk Suplai Daya Pada Distributed Control System (DCS) Di area CLO2-11 PT. IKPP. Universitas Lancang Kuning.

[6] PUIL 2000. BSN (Badan Standar Nasional). 